\title{
Application of Wittgenstein's Sprachspiel in Speaking English Teaching: A Linguistic Philosophical Perspective of Speaking English Teaching for Non- English Major Graduate Students in China

\author{
Hua Jing iD \\ Associate Professor of School of Foreign Languages, East China University of Science and Technology, Shanghai, China \\ $\triangle$ Corresponding Author: Hua Jing, E-mail: huajing0909@163.com
}

\author{
ARTICLE INFORMATION \\ Received: December 22, 2020 \\ Accepted: February 14, 2021 \\ Volume: 3 \\ Issue: 2 \\ DOI: $10.32996 / j e l t a l .2021 .3 .2 .5$
}

\section{KEYWORDS}

Wittgenstein; Sprachspiel; English teaching; Presentation; Speaking English Teaching; Non-English Major Graduates; Classroom activities

\section{ABSTRACT}

"Sprachspiel(Language Game)", a language philosophical term proposed by Wittgenstein, indicates that the meaning of language is in the use of language in all kinds of language games. This concept helps to transfer our focus from abstract language analysis to practical language uses, which throws a light on college English teaching in China. Based on this language philosophical point of view, this paper intends to have some practices on speaking English teaching for non-English major graduates. Based on the analysis of the difficulties and problems of the target students' English learning, this paper puts forward some tentative ways for speaking English teaching in large class. The experimental teaching of a whole school year proves that this new teaching mode enhances students' interests in English and improves students' studying method as well as their Speaking English level. From the survey result, it finds out that this paper also makes an analysis of the surveys conducted both at the very beginning and the end of the school year.

\section{Introduction}

"Sprachspiel" is a concept in modern philosophy of language, with which philosophers and linguists often expound their views on the nature of language, among whom were Saussure, Wittgenstein and Gadamer. As one of the most important philosophers in the 20th century, Wittgenstein developed his philosophical thinking in two distinct periods. The philosophy of Wittgenstein (1912 -22) was mainly reflected in his book Tractatus Logico- Philosophicus, in which he explained the relationship between language, thoughts and the world through Picture Theory of Means. In his book Philosophical Investigations (1953), he criticized his early view of language and put forward the view of meaning that usage is meaning (Xia,2009).

The Outline of the National Medium-and Long-Term Education Reform and Development Plan (2010-2020) points out: "It is necessary to improve the internationalization level of China's education and cultivate a large number of internationalized talents with international vision, familiarity with international rules and ability to participate in international affairs and international competition." In 2017, the Ministry of Education issued the College English Teaching Guide (2018) (hereinafter referred to as the Guide), which positioned college foreign language courses as an important part of China's higher education. It is pointed out that this course is of great significance to promote the coordinated development of knowledge, ability and comprehensive quality of college students, and plays an irreplaceable role in personnel training. The Guide reiterate that the teaching goal of college English is: "to cultivate students' English application ability, at the same time, to develop their autonomous learning ability and improve their comprehensive cultural literacy, so that students can use English effectively in their study, life, social interaction and future work, and meet the needs of the development of the country, society, schools and individuals." The Guide further clarifies the definition of English application ability, that is, "the ability to communicate and exchange in English in study, life and future work". It is emphasized that.

To meet the criteria set by the outline of the National Medium-and Long-Term Education Reform and Development, it is high time that college English teaching should be oriented to the practical use of English and focus on cultivating students' English

K C AL-KINDI CENTER $R$ FOR RESEARCH AND $R$ D DEVELOPMENT Your gateway to world-class research

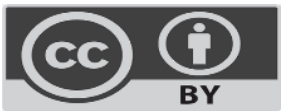

Published by Al-Kindi Center for Research and Development. Copyright (c) the author(s). This open access article is distributed under a Creative Commons Attribution (CC-BY) 4.0 license 
application ability (Wang,2016). This article will discuss the language games theory of Wittgenstein's meaning view and explore its enlightenment to Speaking English teaching for non-English major postgraduates.

\section{Wittgenstein's Sprachspiel-Language Game Theory}

"Sprachspie l (language game)" is the foundation of Wittgenstein's later philosophy of language. "Language Game" runs through the whole book of Philosophy Investigations, which is the basis of Wittgenstein's theory of meaning. The word Sprachspiel emphasizes the fact that speaking language is a part of an activity or a part of a lifestyle. In Wittgenstein's view, language is just like a game. In real life, there are various kinds of games, such as ball games, chess and card games, children's games and so on. Their meaning is embodied in specific games. (Chen, 2003). From Wittgenstein's definition of language games, we can see that he believes that language is inseparable from human behavior, and language games fully reflect the fact that "language is part of actions, or part of life forms".

As an activity, there are two aspects of language. On the one hand, speaking language game itself means language activities, which include certain actions and operations. On the other hand, language games are not just abstract relations among words, but are involved in the real activities as parts of all human activities. The purpose of comparing language to games is to understand and explain language through games. One of the characteristics of language games is its richness and diversity. Wittgenstein provides us with the following examples of philosophical research: giving orders and obeying orders; describing an object according to its appearance, or describing it according to its measurement; constructing an object according to its description (drawing); reporting an event-speculating on the course of the event; putting forward and testing a hypothesisrepresenting the result of an experiment with graphs-and making up a story; Reading stories-acting-singing-guessing-making jokes; Tell jokes-solve an applied arithmetic problem-translate one language into another-request, to express thanks, greetings and pray.(Chen, 2003, 170)

The language game theory provides us an attitude and tool to deal with philosophical problems and reveals the truth that the meaning of words is in their actual usage, thus instead of metaphysical usage, the words are combined with the living real world and people's real-life style, bringing multiple functions of language into play. First of all, regarding language as a game fundamentally excludes the concept of meaning as an entity, thus shifting the study of language from the pursuit of meaning to the emphasis on use. Secondly, Wittgenstein emphasizes the problem of rules in language games and determines different language games according to different rules which gives us great enlightenment in English teaching.

\section{Problems in English Teaching for Non-English Major Postgraduates}

With the increasing cross-culture communication among different countries, it is urgent for college students to improve their ability to use English and communicate with the outside world. And the improvement of English communication ability for Master and Doctoral candidate students has become the most important. The main purposes of English learning for non-English major graduate students who have certain high level of professional knowledge are normally as follows: First, to use English as a tool to read relevant professional materials and be in line with international standards in terms of information sources. Second, to use English to communicate with foreign counterparts in both oral and written forms, including daily conversation and necessary academic exchanges. Postgraduate education, as the elite part of the education field, is of greater significance in China's higher education. The English syllabus for postgraduates suggests that students should master English as a tool to carry out study, research and international exchange of their major. In teaching, the principle of "applying what they have learned" should be adhered to cultivate and improve postgraduates' ability of using English.

College English teaching at the stage of graduate students (non-English majors) faces a rather challenging problem: with all the graduate students having passed the national CET-4 (College English Test Band 4) and most of them having passed the CET- 6 after studying English in the first and second year of college. Before entering the graduate school, they generally went through a short period of intensive postgraduate English training and passed the Postgraduate Entrance Examination of English. Therefore, this group of students have spent a lot of time and effort preparing for the examination of English, which is a compulsory subject for graduate students. Considering the teaching situation of College English in their undergraduate study period where few universities or colleges offer Speaking English courses and the characteristics of students' self-study and review of English which involves mainly doing a large number of written multiple-choice exercises of English subjects, the English reading ability of this group of students has improved considerably. However, due to the lack of Speaking English training, their Speaking English ability and reading ability are seriously out of balance and Speaking English ability is lagged far behind their reading ability. According to our questionnaire survey, most of the students think that the skill of reading is the best one among the five skills of listening, speaking, reading, writing and translating, while speaking is the weakest one. Most of the students never talked with others in English, some of them only answered teachers' questions in English in class, and a considerable number of students could not carry out daily situational conversations in English. 
There are also serious problems in the current postgraduate English teaching: first, the curriculum design at this level is somewhat overlapped with that of undergraduate level. At present, the English curriculum for graduate students follows the college English curriculum model, which mainly includes courses of "intensive reading", "extensive reading" and "listening". Some qualified colleges and universities also offer elective courses to meet the needs of higher-level students. Second, the teaching contents and methods are not improved. Most colleges and universities are still teacher-centered and exam-oriented, following the "spoon-feeding" teaching method, and adopting the "three-steps" teaching method of explaining words, practicing language points and processing exercises. The classroom content is mainly the explanation and infusion of language knowledge points and grammar rules, ignoring the cultivation of postgraduates' English pragmatic ability.Third, the disconnection between English teaching and social needs (Wang, 2020). Generally speaking, postgraduate English teaching should aim to meet the needs of scientific researches and future employment. However, the current teaching cannot provide direct support for its professional research and development, or the needs of the society (Qi, 2019).

Speaking English teaching has always been a weak link and a difficult part in College English teaching in China (Si Bingyue,2014). With the international communication increasingly strengthened, it is urgent that college students should improve their Speaking English so as to communicate with the outside world. Non-English major graduate students are future professionals, who have considerable professional knowledge and are the new force in the talent market in the future. Therefore it is more significant to strengthen English teaching and help to make English language their auxiliary tool to acquire professional knowledge. The main purposes of this group of students to learn English can be as follows: first, they can use English as a tool to read relevant professional materials so that they are in line with international standards in terms of information sources. Secondly, they can use English to communicate with foreign counterparts in Speaking and written cross-cultural communication, including daily conversation and necessary academic exchanges in academic conferences. This paper makes an analysis and discussion on the problems faced in Speaking English teaching for this special group of students, and tries to put forward some feasible teaching methods.

The postgraduate students are adult students, who generally have English learning experience from junior high school to senior high school to college. However, the main channel through which they receive English information is not through "listening" but "reading", which results in the inability of "speaking" . At the same time, it also creates a strong contrast: "speaking" lags far behind "reading". Speaking English teaching has always been a weak link in basic college English teaching. Due to the large class size and uneven level of students, Speaking English teaching is difficult to carry out.Therefore, the 72-hour Speaking English teaching for non-English major postgraduates faces various problems, among which are the choice of forms of Speaking activities in large classes, the choice of difficulty in language materials, and the choice of topics in group discussions.

\section{Application of Sprachspiel to Speaking English Teaching}

The Sprachspiel (language game) put forward by Lugwig Wittgenstein clearly illustrates the process of language acquisition. In Wittgenstein's view, language is a kind of social practice, formed by loosely combined language games. Using language means playing language games. The meaning of language lies in its use, and language is only valuable in use. The whole language game constitutes a way of life. Various uses of language are integrated into specific life forms, and the use of language is placed in the overall social context. People are learning languages in middle schools. The language meaning he understands is first pragmatic meaning. This has given our English educators a good enlightenment: because the meaning of language lies in its use in various language games, English teaching should not be purely language teaching, but should enable students to learn to use English thinking, to speak a foreign language fluently and appropriately is more important than the correct degree, and to improve students' communicative ability.In this sense, English teaching must emphasize the use of language. The teaching process should minimize the one-way input of knowledge from teachers to students, emphasize effective two-way communication with students, and attach importance to the students' own processing and sorting process of knowledge. Let them consciously use foreign languages as communication tools.

The view of language practice shows that language acquisition must be realized through language application practice rather than through language form teaching. In other words, teachers' explanation of vocabulary and grammar rules is not enough to make students become language users. Only when learners observe the language and participate in language practice in specific scenes can they internalize the known language knowledge into language application ability. Middle school English teaching focuses on learning English language knowledge, which belongs to the "learning" stage of English knowledge. At the university stage, especially at the postgraduate stage, attention should be paid to the use of language. Language acquisition must be through language practice, and language games are diverse language practices. Therefore, the English teaching process for university graduate students should carry out various language practice activities to help students to use English fluently.

To emphasize the use of language means that the language teaching mode and teaching methods should be changed accordingly. The new teaching mode should be characterized by language output, that is, student-centered, and achieve the 
teaching purpose of mastering language functions and improving language skills by completing different communicative tasks. Since language is a game, there is interaction between participants. This shows that the traditional teaching mode, which is teacher-led and characterized by language input, is unscientific. Every lesson in foreign language teaching is a real language activity or a variety of language games. Therefore, the role of students should be changed from passive recipients to active participants, actively participate in various language games designed by teachers, and participate in the process of language learning.The forms of games can be dialogues, performances, thematic discussions, debates, etc.In the game, teachers change roles to provide opportunities and motivation for students to communicate, so that students can learn language in use and communicate in communication.

\subsection{Strategies Using Language Game Activities in Spoken English Teaching}

Sprachspiel (Language Game) restores the true nature of language and emphasizes the social life, practical development, rule creativity and rich interest of language. Its educational value and significance to English cannot be ignored. Wittgenstein once provided some examples of language games in his philosophical research, "Describing an object according to its appearance, or describe it according to its measurement-construct an object according to its description (drawing)-report an event-speculate on the course of the event-put forward and test a hypothesis-show the result of an experiment with a chart" is more in line with the characteristics of non-English major postgraduates in using language in professional fields. And based on the characteristics of the above students' English learning situation, there is an adjustment in the arrangement of English courses, changing the combination of traditional intensive reading and extensive reading courses into the to the combination of reading and listening and speaking courses, so as to improve the students' multi-dimensional English ability. Reading is conducted in large classes with more than 100 students in the multimedia classroom, while Speaking English classes are conducted in small classes in the multimedia classroom. There are a total of nine listening and speaking classes, with an average class size of 55 people. Speaking classes for 50 to 60 students must be carefully designed and have their own characteristics in order to ensure orderly and effective performance.

\subsubsection{Warm-up Language Game Activities in English Speaking Class}

The English-Speaking Class can be divided into several steps, and at the beginning of the class, some short-time-period activities can be adopted to warm up the class. Therefore, these specific activities of "Language Games" in graduate English teaching classes can be taken in the following forms:

Personal Speech Presentation : At the beginning of the class, students can take several minutes to stand in front of the class to express their views on some issues around them, or introduce a story or experience that is instructive to them, so that students can get into the habit of speaking English when entering the class, and thus boost up their courage to speak English in public.

Stories Chain Retelling : Teachers prepare humorous stories of about 150 words, and distribute four different stories to students in groups of four, with one student reading one story. After finish reading their stories, the students share their stories with each other in English. Or teachers distribute the stories to the last student in a line of group, ask the last student to read it within the specified time, then retell it to the student in front of him and then to the next student in front until the student who sits in the first row hears the story. The students who hear the story last then tell the whole class the story he heard. Students can compare whose whose version is the closest one to the original story. This kind of activity can enliven the classroom atmosphere. If it is a little dull at the beginning of the class, use of humorous stories can effectively lighten up the atmosphere.

\subsubsection{Major Language Game Activities in English Speaking Class}

After the warming-up activities, the majority of the class time will be devoted to the group language game activities, which will last for 30-60 minutes with the teacher's intervening language guidance or direction from time to time.

Debate Apart from speeches, debates can also be added as a language game. Class debates can first be held in groups of six, with three of them debating on one side of a statement for 25 minutes or so. After that, choose two best debaters from each group to debate in a class level. The debate activity can help to train students' English expressive and thinking ability, as students speak English for the purpose of expressing their thoughts instead of speaking English for the sake of speaking English. Thus, it can help to achieve the purpose of communication and embodying the principle of communication. The topic of the debate was announced one week in advance, allowing students to look for relevant information. Debate can make students have stronger motivation to participate and can stimulate students to refute each others' views in English with great enthusiasm. The topic of the debate was arranged one week in advance for the students to look up relevant information. Due to the large class size, it is proposed to divide the class into two steps. At first, it will be divided into small groups with three students from each side, and then each group will elect two representatives to participate in the class debate. This helps the whole class to participate actively. 
Debate can make students have stronger motivation to participate and can stimulate students to refute each other's views in English with great enthusiasm.

Project Presentations: Demonstration speech means that students should write the outline of the speech on a slide film suitable for projection, or they can make a demonstration courseware and project it on a large screen. The fatal weakness of traditional forms such as reading or reciting speeches is that they cannot demonstrate the contents of the speeches, especially some profound and difficult academic theories and statistical data, which cannot be displayed to the audience simply and clearly. The demonstration speeches can make up for this shortcoming and are in line with the academic characteristics and English expression ability of non-English major graduate students. Presentations will be widely used in student work in the future. Planning statements will be made in the company, papers will be read out at international conferences, work report products will be released and introduced in the working environment, business negotiations, conference speeches, discussions and exchanges, opinions on a certain topic in life and so on will all be elaborated by means of PPT outline display. Attention should be paid to the selection of themes in the process of implementing demonstration speech teaching. Let the students choose the topic of interest so that they can speak well. The theme of the speech may include: introducing characters, such as oneself, classmates or teachers-expressing the personality characteristics of ordinary characters in English to introduce oneself, and the content should include the past, present, future, as well as their own advantages and disadvantages, in order to recall their own growth history, face up to the current situation and imagine the future plans. In the process of introduction, you can introduce others by showing photos or self-portraits of different ages through projectors, list some questions in advance, and conduct on-the-spot interviews. The purpose is to learn to discover the most outstanding qualities and characteristics of the introduced person, because the audience is interested in vivid and concrete facts, not abstract and difficult theories. This kind of speech can greatly satisfy the audience's desire to understand other people's mentality, and will generally get a good response. Introduce things, express the characteristics or historical origin of common things in English, use English as a tool to express the professional knowledge learned during the undergraduate or working period, and learn and exercise your English-Chinese language conversion ability in the process of expression. For example, business school students demonstrate their marketing strategy for a product promotion. Students majoring in tourism show tour routes or tour products; Students majoring in industrial design introduce their products. Students majoring in machinery should promote new machines or new technologies developed by themselves. Students majoring in social public management introduce social problems or new management concepts; Students majoring in environmental protection introduce the use of some kind of environmental protection energy and so on. Introduce someone in your field of expertise. Reading the original English biographies, there will be key figures in the development of any field in different processes. This topic can encourage students to read at least one original English book in a semester and experience the beauty of authentic English.

Demonstration speech has great advantages: when demonstrating their projects, students talk more with effective visual aids for the audience. Especially those carefully designed slide background and animation effect can greatly attract the attention of the audience and greatly reduce the loss of information in the process of transmission. Students are the focus of the demonstration speech and teachers are listeners. Other students are encouraged to give evaluation and comments. The topic of each presentation speech is chosen by students themselves, and the presentation is within 3 minutes. After the speech, students should answer the questions from classmates and teachers. The whole process of the speech is about 10 minutes. The teacher's duty is to sum up the strong and weak points of the students' demonstration speeches and give them suggestions to improve. As for the merits, the teacher praised them greatly. For deficiencies, the teacher can write a written prompt on an evaluation form. In addition, each speech of the students is recorded on a personal special video tape, and when they return home, they can watch the whole speech process and discover their own advantages and disadvantages. Presentations can train students to express their opinions in a comprehensive and concise way in a limited time according to international practice. More importantly, they can make the audience understand and reach the effect of persuasion or agitation.

Demonstrative speeches and debates based on the theory of "Sprachspiel (Language Game) " allow students to participate in language learning and use activities from their most appropriate starting points and interesting perspectives. The demonstration speech can not only cultivate graduate students' correct views of language learning and autonomous learning ability. Infiltrating language games in language teaching will achieve twice the result with half of the effort. "Language Game" is essentially a communication activity among subjects, a human activity, not the end of language. .

\subsection{Application of "Language Game" in English Speaking Activity Topic Selection}

According to the questionnaire survey, it is found that almost all the students do not have the basis of Speaking English courses, and they know little about the speech rules in Speaking English and some functional languages in daily life. Therefore, part of the Speaking English class will be devoted to basic and simple functional language learning to improve students' daily communicative competence. In addition, it is supplemented by relevant audio-visual materials, with moderate difficulty and little hearing impairment. It is mainly used to familiarize students with daily life scenes. 
Good discussion topics should stir up students' excitement and the scope of a discussion topic must be controlled within a certain limit, otherwise the discussion will be endless. The choice of topic should have the following characteristics.

\subsubsection{Topics reflecting students' lives and controversial}

The topics are better to be closely related to students' campus lives and reflects the characteristics of college students' study environment. For example, one can talk about the students' right and wrong in scoring teachers, or the students' cheating mentality, or one can talk about the advantages and disadvantages of students' dormitory management when they rent houses outside. Since these problems concern almost everyone or the people around them, students can express their views on them.

\subsubsection{Topics reflecting hot social issues and culturally influential}

It is closely related to real life and conforms to the characteristics of graduate students' age and ideological depth. Teachers should consciously explore new things, capture new phenomena, and design them into topics that can be close to the life of contemporary college students through processing and sorting. For example, we learned from media reports that US NBA basketball superstar Yao Ming sued the global soft drink giant Coca-Cola Company for using his portrait and demanded 10 cents compensation for mental damage. In this case, students can first talk about their views on celebrity reports.

\subsubsection{Topics showing personal characteristics and unpredictable}

Students have different individuals and personalities, so some topics about their own development prospects are unpredictable. For example, the ideal occupation, the criteria for choosing the ideal occupation, or the criteria for choosing friends in the ideal, and their different criteria for choosing spouse, or the relationship between money and success, or the definition of happiness, etc. For such a topic, everyone can think from the perspective of their own personal characteristics.

\section{Experimental Practices in Speaking English Teaching}

\subsection{Teaching Arrangements}

There is one academic year for the English classes for non-English major postgraduates, of which Speaking English is taught twice a week for a total of 72 hours. The teaching goal is that students master basic functional conversational expressions at the end of the first semester. At the end of the second semester, students are required to be able to express their ideas in basic English and to give a report for about 5-10 minutes without prompting. The specific arrangements are as follows:

\section{$1^{\text {st }}$ Semester}

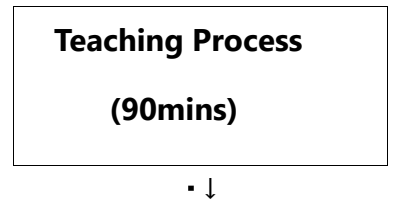

\begin{tabular}{|c|c|c|c|c|c|c|c|}
\hline $\begin{array}{l}\text { Personal } \\
\text { speech } \\
\text { (10-15 } \\
\text { minutes) }\end{array}$ & $\begin{array}{l}\text { Functional } \\
\text { language } \\
\text { learning } \\
(10-15 \\
\text { minutes) }\end{array}$ & $\begin{array}{l}\text { Pair exercises } \\
\text { (Communication } \\
\text { Task Exercise } \\
\text { 15-20 Minutes) }\end{array}$ & $\begin{array}{l}\text { Topic } \\
\text { background } \\
\text { introduction } \\
\text { (5 minutes) }\end{array}$ & $\begin{array}{l}\text { Screening of } \\
\text { relevant } \\
\text { audio-visual } \\
\text { materials } \\
\text { (10 minutes) }\end{array}$ & $\begin{array}{l}\text { Group } \\
\text { activities } \\
(15-20 \\
\text { minutes) }\end{array}$ & $\begin{array}{l}\text { Panel report } \\
\text { (10 minutes) }\end{array}$ & $\begin{array}{l}\text { Teachers' } \\
\text { Summary } \\
\text { and } \\
\text { Comments } \\
\text { (5 Minutes) }\end{array}$ \\
\hline
\end{tabular}




\section{$2^{\text {nd }}$ Semester}

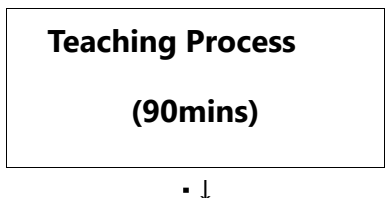

$\cdot \downarrow$

\begin{tabular}{|c|c|c|c|c|c|c|}
\hline $\begin{array}{l}\text { Personal } \\
\text { speech } \quad(10-15 \\
\text { minutes) }\end{array}$ & $\begin{array}{l}\text { Retelling } \\
\text { English games } \\
\text { or stories (10- } \\
15 \text { minutes) }\end{array}$ & $\begin{array}{l}\text { Topic } \\
\text { background } \\
\text { introduction } \\
\text { (5 minutes) }\end{array}$ & $\begin{array}{l}\text { Screening of } \\
\text { relevant audio- } \\
\text { visual materials } \\
\text { (10 minutes) }\end{array}$ & $\begin{array}{l}\text { Group } \\
\text { discussion or } \\
\text { debate } \\
\text { (15-20 minutes) }\end{array}$ & $\begin{array}{l}\text { Class-wide } \\
\text { debate } \\
\text { (15-20 minutes) }\end{array}$ & $\begin{array}{l}\text { Teachers' } \\
\text { Summary and } \\
\text { Comments } \\
\text { (5 Minutes) }\end{array}$ \\
\hline
\end{tabular}

Note: The time duration listed in the schedule is for reference only, and it can vary depending on specific topics and the class situation.

\subsection{Characteristics of the Experimental Teaching Arrangements 5.2.1 Gradual and Progressive Teaching Process}

The teaching plan shows the feature of being gradual and progressive in accordance with students' aptitudes, making adjustment and proceeding step by step. Since students have hardly received any specialized Speaking English teaching and have few opportunities to speak English before, they cannot adapt to using English thinking and expressing ideas in the first semester. Therefore, functional language learning and practice are added to the 18-week teaching in the first semester. The process of adapting to students from the beginning of Speaking English enables students to cultivate the habit of speaking English from the basic daily situations, enhances the confidence in Speaking English learning, and emboldens students to speak English. Taking this feature into consideration in the classroom teaching arrangement, in the first stage of each class, about 15 minutes are arranged to learn functional expressions, and pairs of exercises are carried out on the actual scene design, because the scene is practical and close to daily life, and the students are highly motivated.

\subsubsection{Reasonable Combination of Language Materials in Reading and Speaking English Courses}

In view of the fact that the students are actually adults, most of whom have a certain depth of thought and have their own unique views on social issues, the topics chosen to discuss in the speaking English class can be in agreement with the those in the English reading classes. On the one hand, they help students to further understand the text. On the other hand, with the understanding of the text, students can apply the words or ideas from the reading texts when in speaking classes. The combination of reading class and speaking class reflects the combination of language input and output: students can reproduce the language expressions learned from reading classes in their speaking classes, and they can have points to make instead of being at loss of finding words and expressions.

\subsubsection{Creating English Environment with Multimedia Facilities}

As students need a natural English environment to stimulate their enthusiasm for speaking English in the Speaking class, intuitive visual and audio multimedia teaching tools are used to provide the English environment at the right time period for about 10 mins, so that students can feel the English atmosphere personally. In addition, the multimedia slide show is used to play the picture materials related to the discussion content and to provide relevant argumentation skills, sentences and arguments during the debate, which is intuitive and easy to arouse the enthusiasm of students. Using movie clips (Courtroom debates in Kramer VS Kramer) or CNN audio-visual materials (celebrity interviews, such as Yao Ming's lawsuit against Coca-Cola) to create a language environment that integrates authenticity, communication, knowledge and interest, and stimulate students to acquire languages through a large amount of information (Wang Qimin, 2002).

\subsubsection{Diversified Classroom Activities}

The study on attention persistence found that even adult students can only concentrate for 15-20 minutes at the beginning of a class. Therefore, in large class teaching, it is necessary to give short lectures and practice more, combine lectures and practice, and change teaching methods frequently. (Wang Jianxin: 2003) The classroom forms strive to be diverse and embody the principles of communication. First of all, give students 10 minutes for a personal REPORT at the beginning of the class to train their courage to speak in public. Secondly, by taking two people as partners and practicing pairs, we can not only maximize the 
use of classroom time to create opportunities for students to speak, but also embody the principles of communication and achieve the communicative effect. In group discussions, students will form a group of four, five or six and will get prepared on a certain English-Speaking situation in advance related to the topic, with each group member playing a role in it. Then, according to the background information of their different roles, they will propose solutions or express their own views on a certain problem from different angles. For example, to discuss topics related to education and to design the roles of students, parents, teachers and principals to express their opinions on the topic of advantages and disadvantages of examinations, the situation of identical views and inability to discuss due to the same identity is avoided. Debate is the main form of speaking class in the second semester. First, a six-member group is used as a unit to hold an in-group debate with three members on each side, the pros and the cons. The debate lasts about 20 minutes following the procedure of the debate. Then a class scale debate is held with each group selecting two representatives. In the debate, students are trained in use English expressions to express arguments and their English thinking ability is greatly enhanced. Students speak English for the purpose of expressing their thoughts, avoiding the rigid situation of speaking English for the sake of speaking English, achieving the purpose of communication and embodying the principle of communication.

\section{Teaching Effects and Reflection}

According to the above plan, the author tried teaching Speaking English for one academic year. At the end of the semester, the author conducted another questionnaire survey on 150 students from three classes.(145 questionnaires returned)

\subsection{Teaching Effects}

Table 1 Self-assessment Survey on Speaking English Learning of Non-English Major Postgraduates

\begin{tabular}{|c|c|c|c|}
\hline Questionnaire Items & $\begin{array}{l}\text { Responses A } \\
\% \text { (Number of Students) }\end{array}$ & $\begin{array}{l}\text { Responses B } \\
\% \quad \text { (Number of } \\
\text { Students) }\end{array}$ & $\begin{array}{l}\text { Responses C } \\
\% \quad \text { (Number } \\
\text { Students) }\end{array}$ \\
\hline $\begin{array}{l}\text { 1. Your interests in learning English } \\
\text { after one year of Speaking English } \\
\text { class are... }\end{array}$ & $\begin{array}{l}\text { A. improved } \\
82.1 \%(119)\end{array}$ & $\begin{array}{l}\text { B.Reduced } \\
3.4 \%(5)\end{array}$ & $\begin{array}{l}\text { C.No effect } \\
14.4 \%(21)\end{array}$ \\
\hline $\begin{array}{l}\text { 2.Do you think the English learning } \\
\text { method has changed after one year of } \\
\text { Speaking English class? }\end{array}$ & $\begin{array}{l}\text { A. No, still doing written } \\
\text { exercises } \\
6.9 \%(10)\end{array}$ & $\begin{array}{l}\text { B.Yes, listen to English } \\
\text { through movies and TV } \\
\text { programs } \\
93.1 \%(135)\end{array}$ & \\
\hline $\begin{array}{l}\text { 3. After one year of Speaking } \\
\text { English class, your Speaking English } \\
\text { level... }\end{array}$ & $\begin{array}{l}\text { A. significant improvement } \\
7.6 \%(11)\end{array}$ & $\begin{array}{l}\text { B.To some extent } \\
85.5 \%(124)\end{array}$ & $\begin{array}{l}\text { C.No improvement } \\
6.9 \%(10)\end{array}$ \\
\hline $\begin{array}{l}\text { 4. In which way do you think your } \\
\text { Speaking English has improved } \\
\text { compared with a year ago? }\end{array}$ & $\begin{array}{l}\text { A. be able to express ideas } \\
\text { more freely } \\
4.1 \%(6)\end{array}$ & $\begin{array}{l}\text { B.43.4\%(63 people) were } \\
\text { familiar with daily } \\
\text { functional languages. }\end{array}$ & $\begin{array}{l}\text { C.Be able to speak } \\
\text { boldly } \\
52.4 \%(76)\end{array}$ \\
\hline
\end{tabular}

Table 2 Classroom Assessment Survey on Speaking English Learning of Non-English Major Postgraduates

\begin{tabular}{|l|l|l|l|}
\hline Questionnaire Items & $\begin{array}{l}\text { Responses A } \\
\text { \% (Number of Students) }\end{array}$ & $\begin{array}{l}\text { Responses B } \\
\% \text { (Number of Students) }\end{array}$ & $\begin{array}{l}\text { Responses C } \\
\% \text { (Number of Students) }\end{array}$ \\
\hline $\begin{array}{l}\text { 1. What do you think } \\
\text { of your actual gains and } \\
\text { expectations after te } \\
\text { semester ends. }\end{array}$ & $\begin{array}{l}\text { A. perfect match } \\
26.9 \%(39) \\
\text { the same, with } 67.6 \% \text { (9) } \\
\text { people) of the total being } \\
\text { harvested. }\end{array}$ & $\begin{array}{l}\text { C.The difference is too big, } \\
\text { very }\end{array}$ \\
\hline $\begin{array}{l}\text { 2. Do you think it is } \\
\text { advantageous to use } \\
\text { multimedia in Speaking }\end{array}$ & $\begin{array}{l}\text { A yes, it can help to create a a } \\
\text { multi-mensional English } \\
\text { environment. }\end{array}$ & $\begin{array}{l}\text { B.No, speaking practice time } \\
\text { is relatively reduced. } \\
9.7 \%(14)\end{array}$ & \\
\hline
\end{tabular}




\begin{tabular}{|c|c|c|c|}
\hline class? & $90.3 \%(131)$ & & \\
\hline $\begin{array}{l}\text { 3. What do you think is } \\
\text { the most helpful to you in } \\
\text { Speaking English class? }\end{array}$ & $\begin{array}{l}\text { A. audio-visual screening } \\
\text { and listening practice } \\
28.9 \%(42)\end{array}$ & $\begin{array}{l}\text { B.Personal speech, practice } \\
\text { courage. } \\
35.2 \%(51)\end{array}$ & $\begin{array}{l}\text { C.Group discussion, practice } \\
\text { expression. } \\
35.9 \%(52)\end{array}$ \\
\hline $\begin{array}{l}\text { 4. Do you think the } \\
\text { occasional Speaking games } \\
\text { in Speaking class }\end{array}$ & $\begin{array}{l}\text { A. interesting, can improve } \\
\text { interest } \\
78.6 \%(114)\end{array}$ & $\begin{array}{l}\text { B.It's boring. It's a waste of } \\
\text { time. } \\
8 \%(12)\end{array}$ & $\begin{array}{l}\text { C.Interesting but unhelpful } \\
13.1 \%(19)\end{array}$ \\
\hline $\begin{array}{l}\text { 5. What do you think } \\
\text { of the two semesters of } \\
\text { Speaking English class } \\
\text { (multi-choice) }\end{array}$ & $\begin{array}{l}\text { A. in the first semester, } \\
\text { gained a lot and learned } \\
\text { some expressions. } \\
85.5 \%(124)\end{array}$ & $\begin{array}{l}\text { B.The second semester was } \\
\text { very fruitful and I was able } \\
\text { to express my views freely. } \\
40 \%(58)\end{array}$ & \\
\hline $\begin{array}{l}\text { 6. What do you think } \\
\text { of Speaking class debate }\end{array}$ & $\begin{array}{l}\text { A. it is meaningful and worth } \\
\text { advocating. } \\
47.6 \%(69)\end{array}$ & $\begin{array}{l}\text { B.It is useless and most } \\
\text { people will not participate in } \\
52.4 \%(76)\end{array}$ & \\
\hline $\begin{array}{l}\text { 7. The reasons you } \\
\text { think why many students do } \\
\text { not participate in class } \\
\text { debates is (multi-choice) }\end{array}$ & $\begin{array}{l}\text { A. lack of courage in public } \\
20 \%(29)\end{array}$ & $\begin{array}{l}\text { B. unprepared, speechless } \\
49.7 \%(72)\end{array}$ & $\begin{array}{l}\text { C.The standard is too poor } \\
\text { to be laughed at. } \\
30.3 \%(44)\end{array}$ \\
\hline
\end{tabular}

The experimental teaching proves that this teaching mode improves students' interests in learning English, greatly improves students' English learning methods, improves students' Speaking English ability to different degrees, and thus achieves the expected effect of teaching to a certain level.

\subsection{Reflections}

(1) Due to individual differences among students, some students are more active in discussions and speeches, and are more able to use class time for Speaking expression exercises, thus being able to achieve their expected values. However, some students may only speak for a few minutes in two classes, thus it is difficult to obtain the practice effect.

(2) Most of the students are familiar with functional language and understand speech protocols. This shows that students are more sensitive to input learning knowledge than to output language ability.

(3) Debate, as a form of Speaking class activities, requires students to have high language accumulation and language literacy, so it is not quite suitable for non-English major postgraduates. After only one semester's speaking training, the speaking proficiency of this group of students cannot be successfully raised from the primary level to the advanced level. Therefore, the class activities in the second semester should mainly include group discussions, with two to three debates occasionally.

\section{Conclusion}

Based on the "Game Theory", this article reviewed the possible activities of "Game" in English Speaking classes for non-English major postgraduate students in a University in China. A comprehensive teaching modal for two semesters has been proposed and surveys have been done both before and after the teaching practice. It is found out that the effectiveness of the activities of a speaking language training class is the key to the success of a class for both teachers and students. It is crucial that tteachers should carefully design before the class. The teachers' lesson preparation content is not limited to language problems, but also to design various communication activities that can arouse students' interest, and even imagine how to deal with various situations that cannot be expected in advance. Teachers should not only make the activities lively, but also guide students to achieve the objectives of the activities, so that the teaching progress and communication effect can reach the expected goals. The limit of the study is that students in the study are all science students who have their specific weakness and the reflection from the survey may not apply to all students who are studying English. A more comprehensive study with students from more diverse academic backgrounds can be done in the future. 


\section{References}

[1] Chen J.Y. ( 2003). Philosophy of Language, Peking University Press

[2] College English Teaching Guide (the latest edition) .2018. Ministry of Education China in 2017)

[3] Xia L.X. (2009).On the Connotation of the Core Concept of Wittgenstein's Theory of Meaning [J], Qiusuo 01

[4] Qi P. (2019). Research on the Current Situation,Needs and Countermeasures of College English Visual-audio-oral Teaching. Journal of Heilongjiang College of Education, 12

[5] Wu J.S. (2020). Probe into the Path of College Oral English Teaching in the New Era. Heilongjiang Education (Theory \& Practice) 03

[6] Si B.Y. (2014). Analysis of Meta discourse-Based College English Speaking Teaching. Foreign Language Research.01

[7] Wang B. (2020). Research and Countermeasures of Postgraduate Oral English Teaching from the Perspective of Employment. Heilongjiang Education (Theory \& Practice) 10

[8] Wang S.R.(2016). Interpretation of the Key Points of College English Teaching Guide. Foreign Languages 03 